\title{
Role of Modification of Natural Zeolite in Removal of Arsenic from Aqueous Solutions
}

\author{
Ayten Ates, ${ }^{\star}$ İnci Özkan and Gamze Topal Canbaz \\ Department of Chemical Engineering, Engineering Faculty, Cumhuriyet University, 58140 Sivas, Turkey \\ * Corresponding author: E-mail: ates@cumhuriyet.edu.tr; \\ Tel: +90 2191010/2248; Fax: +903462191165
}

Received: 25-01-2018

\begin{abstract}
The adsorption of arsenic from aqueous solution onto natural and modified zeolites was investigated. The natural zeolites were modified by ion-exchange $\left(\mathrm{NH}_{4} \mathrm{NO}_{3}\right)$ and addition of aluminum $\left(\mathrm{Al}_{2}\left(\mathrm{SO}_{4}\right)_{3}\right)$. The natural and modified zeolites were characterized by XRF, XRD, $\mathrm{N}_{2}$ sorption, FTIR, $\mathrm{NH}_{3}$-TPD, zeta potential and SEM. Ion-exchange with $\mathrm{NH}_{4}{ }^{+}$of $\mathrm{NZ}$ results in the significant exchange of most cations and an increase in surface area and pore volume of samples as well as surface acidity. While the introduction of aluminum into the zeolite increased its As (V) removal amount, it decreased its As (III) removal. Ion-exchange with $\mathrm{NH}_{4}{ }^{+}$of the natural zeolite increased significantly its $\mathrm{As}(\mathrm{III})$ and $\mathrm{As}(\mathrm{V})$ adsorption capacity. The adsorption of both $\mathrm{As}(\mathrm{III})$ and $\mathrm{As}(\mathrm{V})$ with natural and modified zeolites obeys pseudo second order kinetics. The Langmuir isotherm model for all adsorbents was best fitted to the isotherm data obtained. The highest adsorption capacity for $\mathrm{As}(\mathrm{III})$ and $\mathrm{As}(\mathrm{V})$ was obtained onto the zeolite modified with ammonia and their calculated qm values are $28.7 \mathrm{mg} / \mathrm{g}$ and $36.6 \mathrm{mg} / \mathrm{g}$, respectively. The calculated thermodynamic parameters indicated that the adsorption process was spontaneous and favorable.
\end{abstract}

Keywords: Natural zeolite; Arsenic; Decationisation; Ion exchange; Adsorption

\section{Introduction}

Arsenic is one of the most toxic elements occurring naturally in environment and its presence in the drinking water can lead to deadly effects on the human health. Due to the toxicological impacts of arsenic, the maximum contaminant level (MCL) for arsenic of $10 \mu \mathrm{g} / \mathrm{L}$ was set by the World Health Organization (WHO). ${ }^{1}$ Furthermore, the arsenic contamination has been reported in numerous regions such as Bangladesh and West Bengal (India) as well as the USA, Argentina, China, Hungary, and Poland. ${ }^{2,3}$

Arsenic species in the environment come from the natural weathering of arsenic-containing rocks, industrial waste discharges and application of arsenical herbicides and pesticides. Drinking water mainly contains inorganic arsenic species, arsenite $\left(\mathrm{AsO}_{3}{ }^{3-}\right)$ and arsenate $\left(\mathrm{AsO}_{4}{ }^{3-}\right)$. Generally, arsenate [As (V)] in natural surface water and arsenite $[\mathrm{As}(\mathrm{III})]$ in the groundwater mainly exist. ${ }^{3}$ As (III) is usually more toxic than As (V) and its removal from water is difficult due to its difficult dissociation. Therefore, As (III) has been oxidized to As (V) and then removed from water by various technologies such as oxi- dation, reverse osmosis, chemical coagulation followed by filtration and adsorption. ${ }^{3-5}$

Among removal technologies, adsorption is the most promising technology due to the advantages of treatment stability, easy operation, lower environmental impacts, and low cost if suitable adsorbent can be either chosen or designed. Recently many materials have been used and studied as adsorbent for removal of As (III) and As (V) from water. In addition to commercial activated carbons, ${ }^{6}$ several types of activated carbons were synthesized and used for the removal of arsenic from water/wastewater. ${ }^{7-10}$ Besides, the reported adsorbents are given as follows: Agricultural products and by-products, industrial by-products/wastes such as chars and coals, ${ }^{10,11}$ red muds, ${ }^{12}$ blast furnace slag, ${ }^{13,14} \mathrm{Fe}(\mathrm{III}) / \mathrm{Cr}(\mathrm{III})$ hydroxide waste, ${ }^{15}$ fly ash, ${ }^{16}$ soil ${ }^{17}$ sand, ${ }^{18-20}$ clay minerals, ${ }^{21-23}$ zeolites, ${ }^{24}$ single or mixed oxides or hydroxides, ${ }^{25-31}$ hydrotalcites, ${ }^{32}$ phosphates, ${ }^{33}$ metal-based materials, ${ }^{34}$ and biosorbents. ${ }^{35-38}$ However, many of these materials cannot be used in developing countries due to their financially infeasible. When natural material as an adsorbent is used, sustainable and cost-effective solutions for the removal of As pollution can be obtained in the low-income regions. Several studies 
have explored a variety of adsorbents for As removal, and it is reported that naturally formed materials provide the benefits due to their abundance and local availability. Among them, natural zeolites have been widely used as an effective adsorbents in treatment of water due to their mechanical and thermal properties. ${ }^{39,40}$

Elizalde-González et al. ${ }^{41}$ reported that adsorption capacity of $\mathrm{H}_{2} \mathrm{AsO}_{4}{ }^{-}$with natural Mexican zeolites, ZMA (Sonora), ZME (Oaxaca), ZMS (San Luis Potosí) and ZMT (Puebla) is more than $\mathrm{H}_{3} \mathrm{AsO}_{3}$ and their iron modified forms insignificantly improve the level of removal efficiency. Arsenic sorption results from aqueous solutions onto clinoptilolite-rich tuffs modified with lanthanum, hexadecyltrimethylammonium or iron of MacEdo-Miranda and Olguín ${ }^{42}$ showed that arsenic removal depends on the origin of the zeolitic material, the nature of the arsenic chemical species, the $\mathrm{pH}$ and characteristics of the modified natural zeolites. As $(\mathrm{V})$ adsorption from aqueous solutions onto clinoptilolite-heulandite-rich tuffs modified with iron, manganese, or a mixture of both iron and manganese was studied by Jiménez-Cedillo et al. ${ }^{40}$ They reported that adsorption of $\mathrm{As}(\mathrm{V})$ on the modified clinoptilolite-rich tuffs depends on the metallic species introduced into zeolites, the chemical nature of the metal introduced, and the interaction between the different metallic chemical species on the zeolite surface. Consequently, the studies on natural and modified zeolites showed that the type and charge of the zeolite framework mostly affect their adsorption mechanisms and capacities. Furthermore, the other important parameter effecting adsorption mechanisms and capacities can be sorted such as the amount of aluminium present in the zeolite, the size and shape of the pores, the phase composition of the zeolitic material, the nature and concentration of the extra-framework cationic species and the $\mathrm{pH}$ of the solution along with the size and distribution of zeolite particles, the temperature of adsorption, etc.. ${ }^{43}$

After ammonia treatment of the zeolites, $\mathrm{Na}^{+}$and $\mathrm{Ca}^{2+}$ with $\mathrm{NH}_{4}{ }^{+}$are mostly exchangeable in contrast to partly exchangeable of $\mathrm{Fe}^{3+}$ and $\mathrm{Mg}^{2+}$ in zeolites. ${ }^{44}$ The introduction of aluminium into zeolites was studied by Kamali et al. ${ }^{45}$ and then the Ates ${ }^{46}$ applied it into natural zeolite obtained from Sivas-Yavu of Turkey for removal of manganese from drinking water and its adsorption capacity increased two times with enhanced aluminum content.

Based on aforementioned results, in this study the natural zeolite originated from Sivas-Yavu of Turkey was modified via ion exchange with $\mathrm{NH}_{4}{ }^{+}$and introduction of aluminum for removal of arsenic from aqueous solution. The natural and modified zeolites were characterized by $\mathrm{XRF}, \mathrm{XRD}, \mathrm{N}_{2}$ sorption, FTIR, $\mathrm{NH}_{3}$-TPD, particle size distribution, zeta potential and SEM. The influence of specific adsorption parameters on removal of arsenic from aqueous solution was studied and the data obtained were applied to isotherm models.

\section{Experimental Method}

\section{1. Material}

Arsenic stock solutions were prepared using 1000 $\mathrm{mg} / \mathrm{L}$ of As (III\&V) prepared with $\mathrm{As}_{2} \mathrm{O}_{3}$ (Fluka, 39436) in $2 \% \mathrm{HNO}_{3}$ for $\mathrm{As}(\mathrm{V})$ and $\mathrm{H}_{3} \mathrm{AsO}_{4}$ (Merck, 1.19773.0500) in $0.5 \mathrm{~mol} / \mathrm{L}$ of $\mathrm{HNO}_{3}$ for As(III). Arsenic solutions used in the batch experiments were obtained by diluting the arsenic stock solution to the desired concentrations with deionized water. $\mathrm{HCl}$ and $\mathrm{NaOH}$ solutions were used to adjust $\mathrm{pH}$ of arsenite and arsenate solutions.

The natural zeolite was obtained from Sivas-Yavu (NZ-Y) region of Turkey and first ball milled to particle size in range of $0.25-0.5 \mathrm{~mm}$. The NZ-Y was washed and dried in an oven at $120^{\circ} \mathrm{C}$ overnight. The zeolite was transformed to the $\mathrm{NH}_{4}$-form by a twofold exchange with a $0.5 \mathrm{M} \mathrm{NH}_{4} \mathrm{NO}_{3}$ solution at $80^{\circ} \mathrm{C}$. After washing and drying, the sample was calcined at $500^{\circ} \mathrm{C}$ for $2 \mathrm{~h}$ and denoted as $\mathrm{NH}_{4}-\mathrm{NZ}-\mathrm{Y}$.

After washing and drying, $1 \mathrm{~g}$ of the NZ-Y was mixed with sodium hydroxide and water with 5:50 mass ratios for $1 \mathrm{~h}$ at $90{ }^{\circ} \mathrm{C}$ and then the mixture was filtered and the filtrate was denoted as Na-NZ-Y.

Preparation of aluminum introduced zeolite is based on the study of Kamali et al. ${ }^{45}$ For preparation of aluminum solutions, sodium chloride, aluminum sulphate $\left(\mathrm{Al}_{2}\left(\mathrm{SO}_{4}\right)_{3}\right)$ and water with 1:5.4:10 mass ratios were mixed to make a clear solution (solution A). Aluminum sulphate, sodium hydroxide and water with 1:1.5:7.8 mass ratios were mixed and heated to make a clear solution (solution B). The A, Na-NZ and B with 1:7.1: 1 mass ratios were mixed at $90^{\circ} \mathrm{C}$ for $2 \mathrm{~h}$ with a mixing rate of $500 \mathrm{rpm}$. The product was filtered, washed and dried at $80^{\circ} \mathrm{C}$. The product was denoted as Al-NZ-Y.

\section{2. Characterization of Samples}

An X-ray fluorescence (XRF, PANanalytical) analyzer was used for the chemical composition of the samples.

The specific surface area and micropore volume of the samples were measured using $\mathrm{N}_{2}$ adsorption-desorption (AUTOSORB 1C) at $-196^{\circ} \mathrm{C}$. The surface area, pore volume and micropore volume were determined by multipoint BET, DFT (Density Functional Theory) and DR (Dubinin-Radushkevic), respectively.

XRD, SEM-EDS and $\mathrm{NH}_{3}$-TPD results of natural and modified samples were reported in the previous study. ${ }^{46}$

The effect of adsorbent on solution $\mathrm{pH}$ was measured with time $(0-7 \mathrm{~h})$ for $2 \mathrm{~g} / \mathrm{L}$ adsorbent in distilled water.

Zeta potential measurements were conducted using a zetameter (Malvern Zetasizer- Nano-Z). $0.005 \mathrm{~g}$ of samples was suspended in $100 \mathrm{ml}$ of water and the particles were homogenized at $2 \mathrm{~h}$ using an ultrasonic bath. After ultrasonication, the aqueous suspension was equilibrated at different $\mathrm{pH}$ values for $30 \mathrm{~min}$. The equilibrated slurry 
was injected into the micro electrophoresis cell using disposable syringes. Prior to each measurement, the electrophoresis cell was washed repeatedly before reuse.

\section{3. Adsorption Experiments}

Batch adsorption experiments were carried out in a glass flasks $(20 \mathrm{~mL})$ using a magnetic shaker (IKA Magnetic stirrer RO10) at $25^{\circ} \mathrm{C}$ at a constant agitation of 200 rpm. In the kinetic studies suspensions containing the range of $25-200 \mathrm{mg} \mathrm{L}^{-1}$ of $\mathrm{As}(\mathrm{III} \& \mathrm{~V})$ were stirred for different periods of time at optimum $\mathrm{pH}$. After the reaction, suspensions were centrifuged at $5000 \mathrm{rpm}$ for $3 \mathrm{~min}$ in order to separate the solution and solid. The initial and non-adsorbed concentrations of As(III \& V) in supernatants were determined by hydride generation atomic absorption spectroscopy (HG-AAS)- and ICP-MS (Thermo Scientific iCAP Q Series ICP-MS).

During adsorption of As(III \& V), dissolution of cations with varying $\mathrm{pH}$ was studied for $20 \mathrm{~cm}^{3}$ solution containing $50 \mathrm{mg} \mathrm{L}^{-1}$ of As $(\mathrm{V})$ and $0.02 \mathrm{~g}$ of adsorbent for $3 \mathrm{~h}$. After adsorption, cations in supernatants were measured by ICP-MS. Adsorption studies of As(III \& V) onto NZ-Y, $\mathrm{NH}_{4}$-NZ-Y and Al- NZ-Y were conducted using the same procedure in sufficient time for varying feed solution concentrations (25-200 $\left.\mathrm{mg} \mathrm{L}^{-1}\right)$ at different temperatures (298$313 \mathrm{~K}$ ). All results were averaged values of duplicate tests.

The adsorption capacity $\left(\mathrm{q}_{\mathrm{e}}, \mathrm{mg} \mathrm{g}^{-1}\right)$ and removal percent (\%) of As(III \& V) were determined using following equations:

$$
q_{e}=\frac{\left(C_{o}-C_{e}\right) V}{m}
$$

Removal percent $(R, \%)=\frac{C_{0}-C_{e}}{C_{0}} x 100$

where $C_{0}$ and $C e$ are the initial and final concentrations of $\mathrm{As}(\mathrm{III} \& \mathrm{~V})\left(\mathrm{mg} \mathrm{L}^{-1}\right)$, respectively, $V$ is the volume of solution (L) and $m$ is the amount of adsorbent $(\mathrm{g})$.

In order to investigate the nature and mechanism of arsenic adsorption with natural and modified zeolite, several models such as pseudo-first-order, pseudo-second-order and intra-particle diffusion were applied. ${ }^{44}$ For this aim, the adsorbents were loaded in the stirrer cell to be spun at $1500 \mathrm{rpm}$ to cause a vigorous flow of solution. The diffusional resistances in the liquid film were neglected because of the high rotational speed. $3 \mathrm{~mL}$ of samples was periodically withdrawn from the solution and analyzed using HG-AAS.

The pseudo-first order kinetic model of Lagergren is given as:

$$
\log \left(q_{e}-q_{t}\right)=\log q_{e}-\frac{k_{1}}{2.303} t
$$

where $\mathrm{q}_{\mathrm{t}}(\mathrm{mg} / \mathrm{g})$ is the amount of As adsorbed on the adsorbent at time and $\mathrm{k}_{1}\left(\mathrm{~min}^{-1}\right)$ is the rate constant of pseudo first order kinetic model. ${ }^{47}$

The equation for the pseudo-second order kinetic model ${ }^{47}$ is as follows:

$$
\frac{d q_{t}}{d t}=K\left(q_{e}-q_{t}\right)^{2}
$$

where $\mathrm{q}_{\mathrm{e}}$ and $\mathrm{q}_{\mathrm{t}}$ are the amount of As adsorbed per unit of mass of the adsorbent at equilibrium and time $t$, respectively. Linearized form of pseudo-second order rate kinetics is expressed as follows:

$$
\frac{t}{q_{t}}=\frac{1}{k q_{e}^{2}}+\frac{1}{q_{e}} t
$$

In addition, initial rate of adsorption is $\mathrm{h}$ :

$$
h=k q_{e}^{2}
$$
follows:

The intraparticle diffusion model can be described as

$$
q_{t}=k_{d} t^{\frac{1}{2}}+C
$$

where $k_{p}$ is the intra-particle diffusion rate constant (mg $\mathrm{g}^{-1} \mathrm{~min}^{-0.5}$ ) obtained from the slope and $\mathrm{C}$ is the adsorption constant obtained from the intercept.

The Langmuir model essentially describes the monolayer type of adsorption. ${ }^{48}$ It is expressed as follows:

$$
q_{e}=\frac{q_{m} b C e}{1+b C e}
$$

where $\mathrm{q}_{\mathrm{m}}(\mathrm{mg} / \mathrm{g})$ is the maximum adsorption capacity and $b\left(\mathrm{~L} \mathrm{mg}^{-1}\right)$ is the Langmuir constant.

The Freundlich isotherm is derived from a multilayer heterogeneous adsorption model. The Freundlich isotherm is as follows:

$$
\mathrm{qe}=\mathrm{k}_{\mathrm{F}} \mathrm{Ce}^{1 / \mathrm{n}}
$$

where $\mathrm{k}_{\mathrm{F}}\left(\left(\left(\mathrm{mg} \mathrm{g}^{-1}\right)\left(\mathrm{mg} \mathrm{L}^{-1}\right)^{-n}\right)\right.$ is the Freundlich adsorption constant related to adsorption capacity and $n$ is the adsorption intensity. The $1 / \mathrm{n}$ value was between 0 and 1 , indicating that the adsorption was favorable at the studied conditions.

In order to express the adsorption mechanism with Gaussian energy distribution onto a heterogeneous surface, equilibrium data was applied to Dubinin-Radushkevich (DR) model shown as following:

$$
\begin{aligned}
& \mathrm{qe}=\mathrm{qs} \exp \left(-\mathrm{k} \varepsilon^{2}\right) \\
& \text { lnqe }=\ln \mathrm{qs}-\mathrm{k} \varepsilon^{2}
\end{aligned}
$$




$$
\mathrm{E}=1 /(2 \mathrm{k})^{0.5}
$$

where $\boldsymbol{\varepsilon}$ (Polanyi Potential, $/ \mathrm{mol})$ is $[\mathrm{RT} \ln (1+(1 / \mathrm{Ce})]$, qe refers to the amount of As adsorbed per unit weight of adsorbent $\left(\mathrm{mg} \mathrm{g}^{-1}\right)$, qs refers to theoretical isotherm saturation capacity $\left(\mathrm{mg} \mathrm{g}^{-1}\right), \mathrm{C}_{\mathbf{e}}$ is the equilibrium concentration of As in aqueous solution, $\mathrm{k}$ is a constant related to adsorption energy, $\mathrm{R}$ is the ideal gas constant and $\mathrm{T}$ the temperature $(\mathrm{K}){ }^{49-51}$

\section{3. 1. Adsorption Thermodynamics}

Gibbs free energy change $\left(\Delta \mathrm{G}^{\circ}\right)$, enthalpy change $\left(\Delta \mathrm{H}^{\circ}\right)$ and entropy change $\left(\Delta \mathrm{S}^{\circ}\right)$ of the adsorption of As (III\&V) were evaluated. The value of $\Delta \mathrm{G}^{\circ}$ is a crucial due to an indication of spontaneity of a chemical reaction, which can be calculated as follows:

$$
\Delta G=R T \operatorname{In} K_{c}
$$

where $K c$ ((the amount of As in adsorbent)/(the amount of As in solution)) is the distribution coefficient.

The enthalpy change $(\Delta \mathrm{H})$ and entropy change $(\Delta \mathrm{S})$ were estimated from the following equation:

$$
\ln K_{c}=\frac{\Delta S}{R}-\frac{\Delta H}{R T}
$$

\section{Results and Discussion}

\section{1. Characterization of Samples}

$\mathrm{XRD}$ results in previous studies ${ }^{52,53}$ showed that NZ-Y contains mainly clinoptilolite $\left((\mathrm{Na}, \mathrm{K}, \mathrm{Ca})_{2-3} \mathrm{Al}_{3}\right.$ $\left.(\mathrm{Al}, \mathrm{Si})_{2} \mathrm{Si}_{13} \mathrm{O}_{36} \cdot 12\left(\mathrm{H}_{2} \mathrm{O}\right)\right)$ and mordenite $\left(\left(\mathrm{Ca}, \mathrm{Na}_{2}, \mathrm{~K}_{2}\right)\right.$ $\left.\mathrm{Al}_{2} \mathrm{Si}_{10} \mathrm{O}_{24} \cdot 7 \mathrm{H}_{2} \mathrm{O}\right)$ as well as quartz $\left(\mathrm{SiO}_{2}\right)$ and feldspar $\left(\mathrm{KAlSi}_{3} \mathrm{O}_{8}-\mathrm{NaAlSi}_{3} \mathrm{O}_{8}-\mathrm{CaAl}_{2} \mathrm{Si}_{2} \mathrm{O}_{8}\right.$ ). Based on XRD and SEM results, ${ }^{53}$ after treatment with $\mathrm{NH}_{4} \mathrm{NO}_{3}$ of NZ-Y, the peak intensities are hardly changed and the particle size of NZ-Y decreased. Composition results listed in Table 1 show that the ion exchange with $\mathrm{NH}_{4}{ }^{+}$of the zeolite leads to the efficient removal of $\mathrm{Sr}^{2+}$ and $\mathrm{Ca}^{2+}$ and the partial removal of $\mathrm{Mg}^{2+}, \mathrm{K}^{+}, \mathrm{Ba}^{2+}$ and $\mathrm{Ti}^{4+}$ because cations such as $\mathrm{Fe}^{3+}, \mathrm{Mg}^{2+}$ and $\mathrm{K}^{+}$are strongly bound in clinoptilolite. In contrast, after the treatment with $\mathrm{NaOH}$ and the introduction of aluminum, mordenite and feldspar phases disappeared and the phase intensity of clinoptilolite and quartz decreased significantly. In addition, the treatment with $\mathrm{NaOH}$ led to the formation of hydroxysodalite at $35^{\circ}$ of $2 \theta^{54}$ and significant removal of $\mathrm{Sr}^{2+}$ along with significant dealumination and desilication in NZ-Y. It was reported that the $\mathrm{Si}-\mathrm{O}-\mathrm{Al}$ bond is relatively stronger than the $\mathrm{Si}-\mathrm{O}-\mathrm{Si}$ bond because of the negative charge of $\mathrm{AlO}_{4}{ }^{-}$tetrahedron. ${ }^{55}$ The desilication process strongly relates with the concentration of $\mathrm{NaOH}$ solution in order to the extraction of Si from the zeolites. The aluminum introduction into Na-NZ-Y led to an increase in the aluminum content and the percentage of various cations such as $\mathrm{Mg}^{2+} \mathrm{Ca}^{2+}$ and $\mathrm{Fe}^{3+}$ in the zeolite.

The $\mathrm{N}_{2}$-physisorption ${ }^{52,53}$ showed that the shape of NZ-Y is consistent with Type I, which is characteristic of microporous materials with a plateau at high relative pressures. After ion exchange with $\mathrm{NH}_{4}^{+}$, a considerable increase in the specific surface area, micropore volume and total volume of zeolites was observed in Table 1. These results are in accordance with those reported previously. ${ }^{53,56,57}$ In addition, the replacement of the metal cations by $\mathrm{H}^{+}$and/or removal of some impurities may lead to an increase of the surface characteristics. The surface area and micropore volume of samples treated with $\mathrm{NaOH}$ significantly decreased due to loss of crystalline, sintering of phases and the formation of amorphous material. The aluminum introduction into Na-NZ-Y slightly increased its surface area and micropore volume due to reorganization of crystal structure in the presence of aluminum.

$\mathrm{NH}_{3}$-TPD results ${ }^{53}$ showed that the $\mathrm{NH}_{4}{ }^{+}$exchange of NZ-Y leads to a significant increase in the total acidity of the zeolite. This is related with the exchange of the $\mathrm{K}^{+}, \mathrm{Fe}^{3+}$ and $\mathrm{Ca}^{2+}$ ions with $\mathrm{NH}_{4}{ }^{+}$and $\mathrm{H}^{+}$since the strong acid sites $\left(>300{ }^{\circ} \mathrm{C}\right.$ ) generally result of structural hydroxyl groups. The generation of these framework $\mathrm{OH}$ groups and the reappearance of structural hydroxyls blocked by cations can be obtained by means of decationisation and dealumination, which is consistent with FTIR results reported in reference. ${ }^{53}$ In addition, the increase in the intensity of peak at higher than $600{ }^{\circ} \mathrm{C}$ is a result of hydroxylation of samples. Aluminum introduction into Na-NZ-Y leads to an increase in a number of weak acid sites and a decrease in a number of strong acid sites, which is related with increasing extra-framework aluminum content and $\mathrm{OH}$ groups as seen in XRF and FTIR results reported in reference. ${ }^{53}$

The $\mathrm{pH}$ variation of solution in the presence of adsorbents is illustrated in Fig. 1. For 30 min- contact time,

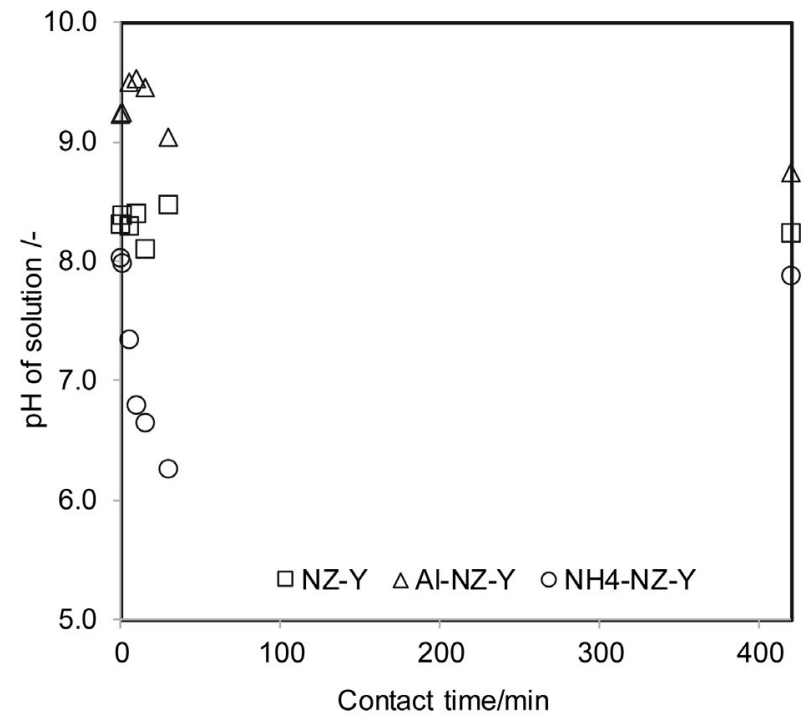

Figure 1. $\mathrm{pH}$ variation of solution with adsorbent 
Table 1. The composition, surface area and pore characteristics of natural and modified zeolites.

\begin{tabular}{lcccc}
\hline Element & $\begin{array}{c}\text { NZ-Y } \\
\text { wt.\% }\end{array}$ & $\begin{array}{c}\mathbf{N H}_{\mathbf{4}} \text {-NZ-Y } \\
\text { wt.\% }\end{array}$ & $\begin{array}{c}\text { Na-NZ-Y } \\
\text { wt.\% }\end{array}$ & $\begin{array}{c}\text { Al-NZ-Y } \\
\text { wt.\% }\end{array}$ \\
\hline $\mathrm{Al}$ & 15.4 & 17.0 & 11.6 & 19.5 \\
$\mathrm{Si}$ & 79.6 & 80.2 & 77.0 & 70.6 \\
$\mathrm{Mg}$ & 1.25 & 0.74 & 2.2 & 2.4 \\
$\mathrm{Ca}$ & 2.1 & 0.3 & 5.2 & 4.3 \\
$\mathrm{~K}$ & 0.4 & 0.3 & 0.7 & 0.6 \\
$\mathrm{Fe}$ & 0.7 & 0.9 & 1.8 & 1.4 \\
$\mathrm{Sr}$ & 3.9 & 0.04 & 0.6 & 0.5 \\
$\mathrm{Ti}$ & 0.2 & 0.2 & 0.4 & 0.3 \\
$\mathrm{Ba}$ & 0.05 & 0.04 & 0.18 & 0.14 \\
$\mathrm{Zr}$ & 0.01 & 0.01 & 0.04 & 0.04 \\
\hline & Surface area and pore characteristics & & \\
\hline $\mathrm{SA}^{\mathrm{a}}\left(\mathrm{m}^{2} \mathrm{~g}^{-1}\right)$ & 62.4 & 83.2 & 12.9 & 37.4 \\
$\mathrm{~V}_{\mathrm{T}}\left(\mathrm{cm}^{3} \mathrm{~g}^{-1}\right)$ & 0.140 & 0.223 & 0.037 & 0.220 \\
$\mathrm{~V}_{\mathrm{MP}}\left(\mathrm{cm}^{3} \mathrm{~g}^{-1}\right)$ & $2.7 \times 10^{-2}$ & $2.8 \times 10^{-2}$ & $5.1 \times 10^{-3}$ & $1.42 \times 10^{-2}$ \\
$\mathrm{D}^{\mathrm{c}}(\AA)$ & 94 & 107 & 116 & 241 \\
\hline
\end{tabular}

${ }^{\text {a }}$ Surface area calculated using Multipoint BET; ${ }^{\mathrm{b}}$ Micro pore volume calculated using DR method; ${ }^{\mathrm{c}} \mathrm{Av}-$ erage pore diameter determined by DFT

whereas NZ-Y and Al-NZ-Y change insignificantly $\mathrm{pH}$ of solution, $\mathrm{NH}_{4}-\mathrm{NZ}-\mathrm{Y}$ decreases significantly the $\mathrm{pH}$ of solution due to dissolution of cations. However, after 7 $\mathrm{h}$-contact time, scenario of $\mathrm{pH}$ variation changed and all adsorbents decreased slightly $\mathrm{pH}$ of solution. After 7 $\mathrm{h}$-contact time, the variation of $\mathrm{pH}$ can be listed as 0.07 for NZ-Y, 0.49 for Al-NZ-Y and 0.15 for $\mathrm{NH}_{4}$-NZ-Y as seen in Fig. 1. The $\mathrm{pH}$ variation with increasing contact time may be due to dissolution of cations in distilled water.

Fig. 2a illustrates final $\mathrm{pH}$ value with varying solution $\mathrm{pH}$. The final $\mathrm{pH}$ value of solution for all samples is almost proportional with the initial $\mathrm{pH}$ until $\mathrm{pH}$ 5. However, above $\mathrm{pH} 5$, it shifts slightly higher values when the initial $\mathrm{pH}$ is increased, particularly for ranges from $\mathrm{pH} 5$ to 9. This might be due to partial solubility of silica and cations under basic conditions.

Fig. $2 \mathrm{~b}$ shows the results of zeta potential measurements of the natural and modified zeolites. In addition to zeta potential, the point of zero charge $\left(\mathrm{pH}_{\mathrm{PZC}}\right)$ of samples was estimated where the net surface charge on metal oxides is zero, which was determined using $\Delta \mathrm{pH}$ from Fig. 2a. The PZC of natural zeolite is $\mathrm{pH}$ 5.2, confirmed the results reported by various researchers. ${ }^{58,59}$ The PZCs of $\mathrm{NH}_{4}$ $\mathrm{NZ}-\mathrm{Y}$ and $\mathrm{Al}-\mathrm{NZ}-\mathrm{Y}$ are $\mathrm{pH}=5.4$ and $\mathrm{pH}=1.5$, respectively. Introduction of aluminum into natural zeolite decreases its PZC, which may be due to increasing aluminum content. a)

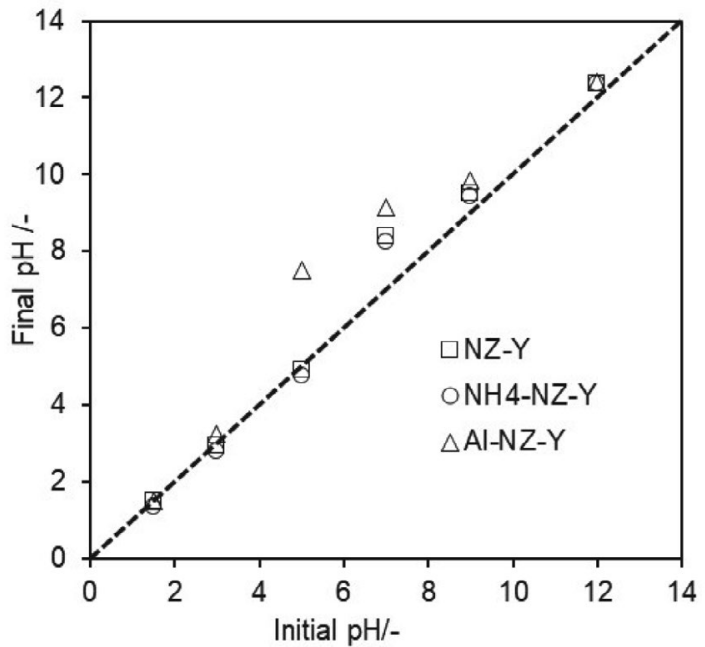

b)

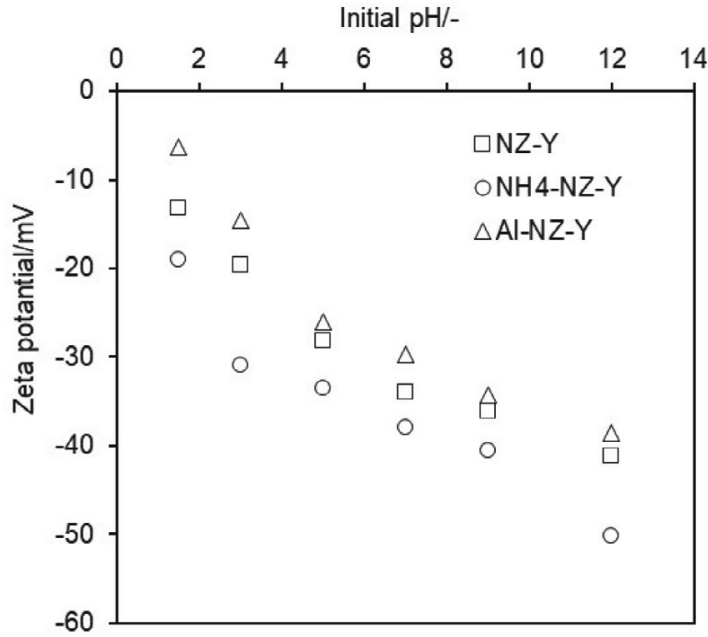

Figure 2. pH variation (a) and zeta potential (b) of natural and modified zeolites. 


\section{2. Adsorption of Arsenic by the Natural and Modified Zeolites}

\section{2. 1. Influence of $\mathrm{pH}$}

The $\mathrm{pH}$ of solution during adsorption process affects the surface characteristics and speciation of adsorbate. Therefore, $\mathrm{pH}$ of solution is crucial parameter on the removal of arsenic. The influence of initial solution $\mathrm{pH}$ on the arsenic adsorption with natural and modified zeolites was examined at the $\mathrm{pH}$ values ranging from 1.5 to 9.0 and the obtained results are illustrated in Table 2. The maximum removal amount of $\mathrm{As}(\mathrm{V})$ was found at $\mathrm{pH} 5.0$ for NZ-Y, $\mathrm{pH} 3.0$ for $\mathrm{NH}_{4}-\mathrm{NZ}-\mathrm{Y}$ and $\mathrm{pH} 1.5$ for Al-NZ-Y, indicating that the modification of the zeolites affects significantly optimum As (V) removal $\mathrm{pH}$. However, maximum removal amount of As(III) was observed at pH 7.0 on both NZ-Y and $\mathrm{NH}_{4}-\mathrm{NZ}-\mathrm{Y}$. In this study, As (III) adsorption data on Al-NZ-Y cannot be showed due to it's lower As(III) adsorption capacity. These results show that the adsorption behavior depends on not only the charge properties of the adsorbent surface but also the specific interactions between functional groups on the adsorbent surface and the adsorbed species. ${ }^{49}$ Deliyanni and coworkers ${ }^{60}$ reported that stabile $\mathrm{pH}$ values of As $(\mathrm{V})$ are $\mathrm{H}_{3} \mathrm{AsO}_{4}(\mathrm{pH}<2.25), \mathrm{H}_{2} \mathrm{~A}$ $\mathrm{sO}_{4}^{-}\left(\mathrm{pH}\right.$ 2.25-6.77), $\mathrm{HAsO}_{4}{ }^{2-}(\mathrm{pH}$ 6.77-11.53), and $\mathrm{AsO}_{4}{ }^{3-}(\mathrm{pH}>11.53)$. In addition, it is related with the determined $\mathrm{pH}_{\mathrm{pzc}}$ values of adsorbents that the optimum $\mathrm{As}(\mathrm{V})$ removal $\mathrm{pH}$ and $\mathrm{pH}_{\mathrm{PZC}}$ of $\mathrm{NZ}-\mathrm{Y}$ and $\mathrm{Al}-\mathrm{NZ}-\mathrm{Y}$ are almost same and they are almost 5.0 for NZ-Y and are 1.5 for Al-NZ-Y. A shift between optimum As $(\mathrm{V})$ removal $\mathrm{pH}$ and $\mathrm{pH}_{\mathrm{PZC}}$ of $\mathrm{NH}_{4}-\mathrm{NZ}-\mathrm{Y}$ is observed that it may be related with ammonia dissolved during adsorption. Based on pre-

Table 2. The removal percentage of arsenic (III, V) with natural and modified zeolites as a function of $\mathrm{pH}\left(\mathrm{C}_{\mathrm{Aso}}=100 \mathrm{mg} / \mathrm{L}\right)$.

\begin{tabular}{cccccc}
\hline pH & \multicolumn{3}{c}{ As(V) } & \multicolumn{2}{c}{ As(III) } \\
& NZ-Y & NH4 $_{\mathbf{4}}$-NZ-Y & Al-NZ-Y & NZ-Y & NH $_{4}$-NZ-Y \\
\hline 1.5 & 12.5 & 4.0 & 32.0 & 0.8 & 12.0 \\
3.0 & 18.8 & 12.4 & 14.8 & 4.0 & 25.4 \\
5.0 & 19.0 & 6.8 & 24.8 & 3.6 & 16.3 \\
6.0 & - & - & 7.6 & - & - \\
7.0 & 15.4 & 1.6 & 9.0 & 4.1 & 25.0 \\
9.0 & 6.70 & - & 16.9 & 5.0 & - \\
\hline
\end{tabular}

viously reported results, ${ }^{61}$ as $\mathrm{pH}$ is lower than 6.8 , the amount of multivalent species were dominated by $\mathrm{H}_{3} \mathrm{AsO}_{4}$ and $\mathrm{H}_{2} \mathrm{AsO}_{4}{ }^{-}$in which the surfaces of adsorbent are positively charged and could bind negatively charged $\mathrm{H}_{2} \mathrm{~A}$ $\mathrm{sO}_{4}^{-}$anions, which was responsible for the adsorption via electrostatic attraction and/or ligand change mechanism. ${ }^{62}$

For influence of $\mathrm{pH}$ value in the solution, in the $\mathrm{pH}$ range of $1.5-5.0^{63}$ electrostatic attraction occurs since $\mathrm{As}(\mathrm{V})$ generally exists in the forms of $\mathrm{H}_{2} \mathrm{AsO}_{4}{ }^{-}$and $\mathrm{HAsO}_{4}{ }^{2-}$ and the adsorbents possess negative charge, facilitating arsenic removal. However, an increase in solution $\mathrm{pH}$ leads to the gradual deprotonation of surface hydroxyl groups, made the adsorbents negatively charged, and the adsorption capacity is consequently decreased because of electrostatic repulsion effect. For As (III), the opposite behavior is observed due to its non-ionic $\left(\mathrm{H}_{3} \mathrm{AsO}_{3}\right)$ species. The maximum As(III) removal is found at $\mathrm{pH} 7$ because the adsorbents possess negative charge and the As(III) possesses approximately equimolar mixture of $\mathrm{H}_{3} \mathrm{~A}$ $\mathrm{sO}_{3}$ and $\mathrm{H}_{2} \mathrm{AsO}_{3}{ }^{-}$in the solution. For this result, Dutta et $a .^{64}$ suggested that the formation of surface complex might depend on solution $\mathrm{pH}$.

Table 3 shows concentration $\left(\mathrm{mg} \mathrm{L}^{-1}\right)$ of metals dissolved from adsorbents into solution with varying $\mathrm{pH}$ after $3 \mathrm{~h}$ - contact time. The amount of dissolved cations at $\mathrm{pH}$ 1.5 is high for both NZ-Y and Al-NZ-Y. Increasing $\mathrm{pH}$ leads to a decrease in dissolution, however the dissolution of $\mathrm{Si}$ is insignificantly changed that it should be related with insensitivity of silicon analysis with ICP-MS. Dissolved amount of aluminum from Al-NZ-Y at $\mathrm{pH} 1.5$ is almost three times higher than that of NZ-Y, which is due to dissolution of introduced aluminum into NZ-Y. In order to reduction of aluminum dissolution, further adsorption studies for Al-NZ-Y were done at $\mathrm{pH}=5.0$. Although the amount of $\mathrm{Fe}$ and $\mathrm{Mg}$ with increasing $\mathrm{pH}$ is almost stabile, the amount of $\mathrm{Ca}$ is similar to silicon results.

\section{2. 2. Contact Time and Adsorption Kinetic Studies}

Adsorption capacity of adsorbents with contact time for $\mathrm{As}(\mathrm{V})$ is shown in Fig 3. Although the equilibrium time of $\mathrm{As}(\mathrm{V})$ on NZ-Y and Al-NZ-Y is determined as $120 \mathrm{~min}$, the equilibrium time on the $\mathrm{NH}_{4}-\mathrm{NZ}-\mathrm{Y}$ is $480 \mathrm{~min}$. Slow adsorption rate of $\mathrm{As}(\mathrm{V})$ on $\mathrm{NH}_{4}-\mathrm{NZ}-\mathrm{Y}$ may be due to in-

Table 3. Concentration $\left(\mathrm{mg} \mathrm{L}^{-1}\right)$ of metals dissolved from adsorbent into solution with varying $\mathrm{pH}$ after $3 \mathrm{~h}$ - contact time

\begin{tabular}{|c|c|c|c|c|c|c|c|c|c|c|}
\hline \multicolumn{6}{|c|}{ NZ-Y } & \multicolumn{5}{|c|}{ Al-NZ-Y } \\
\hline $\mathrm{pH}$ & 1.5 & 3 & 5 & 7 & 9 & 1.5 & 3 & 5 & 7 & 9 \\
\hline $\mathrm{Al}$ & 12.77 & 0.59 & 4.94 & 5.73 & 4.58 & 38.5 & 1.19 & 1.27 & 0.91 & 2.32 \\
\hline $\mathrm{Si}$ & 18.01 & 19.31 & 31.34 & 30.86 & 31.54 & 63.0 & 21.0 & 20.80 & 17.12 & 20.10 \\
\hline $\mathrm{Ca}$ & 14.70 & 13.59 & 13.38 & 12.66 & 12.33 & 28.4 & 15.4 & 16.06 & 12.90 & 13.49 \\
\hline $\mathrm{Fe}$ & 2.33 & 1.94 & 3.13 & 3.43 & 2.92 & 13.03 & 1.96 & 2.05 & 1.55 & 2.35 \\
\hline $\mathrm{Mg}$ & 1.47 & 0.82 & 1.13 & 1.09 & 1.01 & 10.24 & 1.87 & 1.81 & 1.20 & 1.47 \\
\hline
\end{tabular}


creasing ion exchange capacity with cation exchange and increasing acidity based on XRF and $\mathrm{NH}_{3}$-TPD results reported in reference. ${ }^{53}$ Equilibrium time of As (III) on ad- sorbents is shown in Fig. 4 and almost opposite trend of $\mathrm{As}(\mathrm{V})$ is observed. Namely, the equilibrium time of As(III) on $\mathrm{NZ}-\mathrm{Y}$ and $\mathrm{NH}_{4}-\mathrm{NZ}-\mathrm{Y}$ is determined as $480 \mathrm{~min}$.
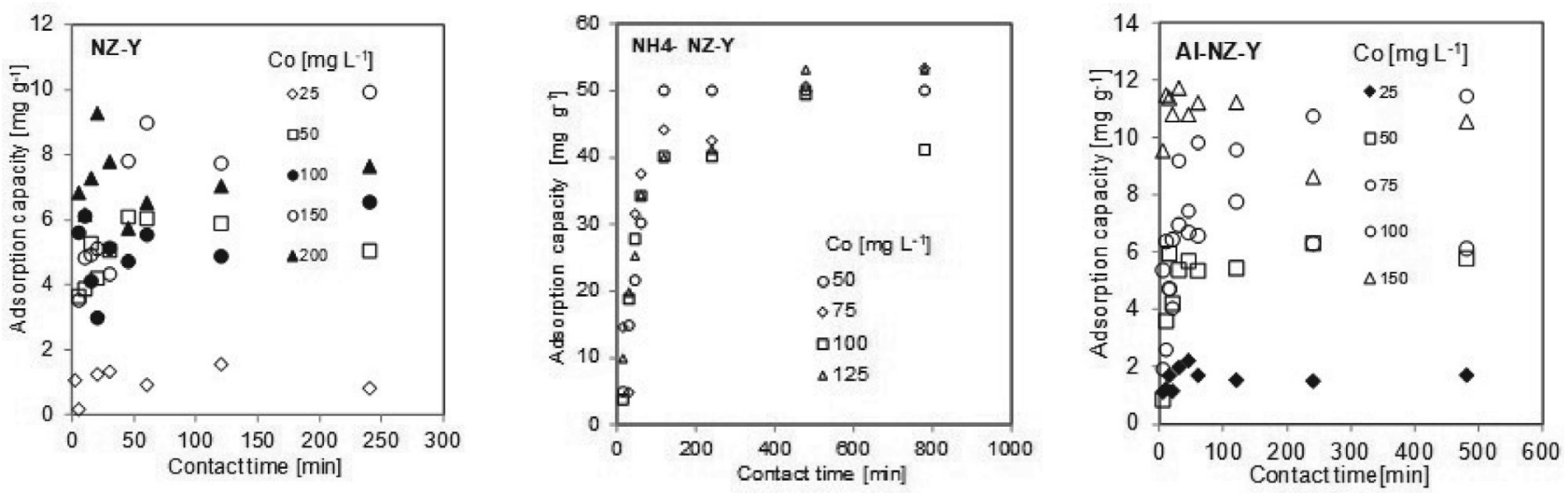

Figure 3. Adsorption capacity of NZ-Y, NH4-NZ-Y and Al-NZ-Y for removal of As(V) as a function of contact time.
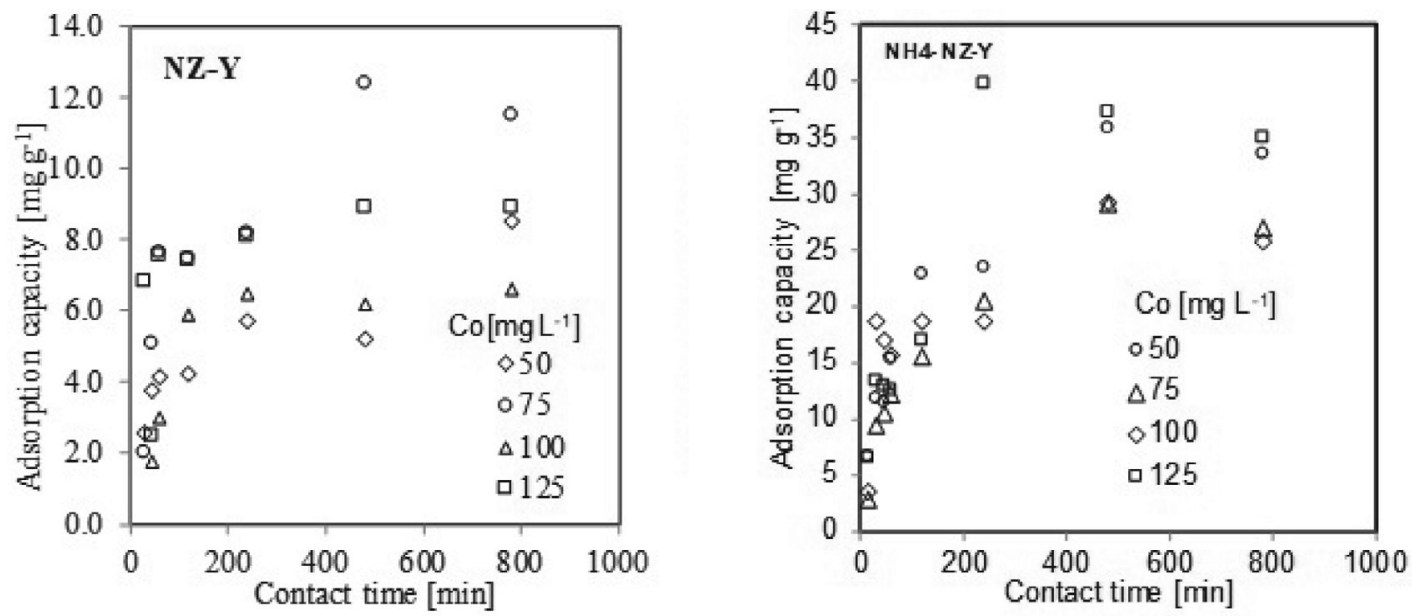

Figure 4. Adsorption capacity of NZ-Y and NH4-NZ-Y for removal of As(III) as a function of contact time.
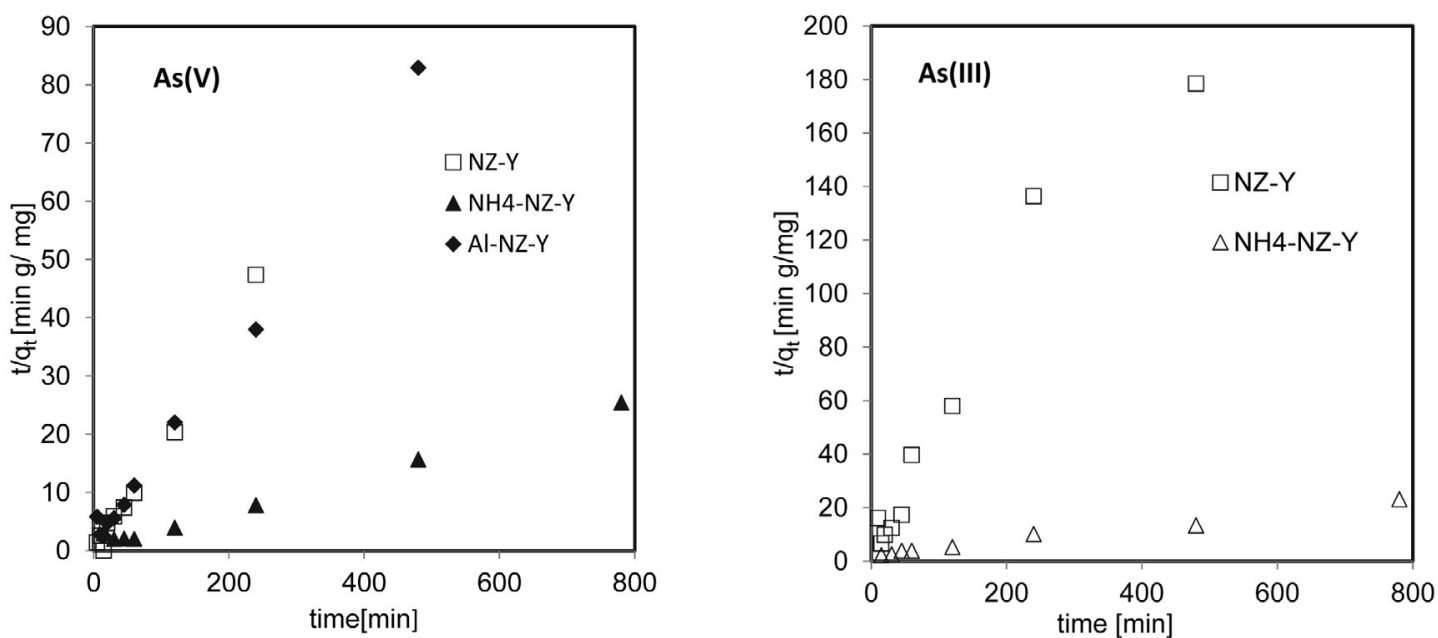

Figure 5. The linear second-order kinetic adsorption data for arsenic by natural and modified zeolites 
To describe the adsorption behavior of an adsorbent, the adsorption results of As (III) and $\mathrm{As}(\mathrm{V})$ by $\mathrm{NZ}-\mathrm{Y}, \mathrm{NH}_{4}$ NZ-Y and Al-NZ-Y shown in Figs 3 and 4 were fitted with pseudo-first-order, pseudo-second-order and intraparticule diffusion kinetic rate equations. Table 4 shows the relevant parameters and correlation coefficients $\left(\mathrm{R}^{2}\right)$ obtained from the kinetic models. Based on correlation coefficients $\left(\mathrm{R}^{2}\right)$, the pseudo-second-order model has higher $\mathrm{R}^{2}$ values for As $(I I I, \& V)$ than pseudo-first-order and intraparticule diffusion models. In addition, the linear second-order kinetic adsorption data for arsenic by natural and modified zeolites are shown in Fig. 5. The finding implies that the adsorption of arsenic occurs in the pores of the adsorbents.

\section{2. 3. Adsorption Isotherms}

Based on the results in Figs. 3 and 4, Langmuir and Freundlich, D-R isotherm models were fitted to adsorption isotherms and the adsorption constants obtained from the isotherms are presented in Table 4. Higher regression coefficient in Table 5 suggests that the Langmuir model is more suitable for arsenic removal than the Freundlich model. This indicates that arsenic adsorption occurs on a homogenous surface irrespective of modification.

qm calculated from the Langmuir parameters represents the monolayer saturation at equilibrium and $b$ indi- cates the binding affinity for arsenic. The high $b$ value indicates a high affinity that the affinity of $\mathrm{NH}_{4}-\mathrm{NZ}-\mathrm{Y}$ for $\mathrm{As}(\mathrm{III} \& \mathrm{~V})$ ions is higher than those of NZ-Y and Al-NZ.

The value of $\mathrm{k}_{\mathrm{F}}$ constant calculated from Freundlich isotherms is changed depending on the type of adsorbent. $1 / \mathrm{n}$ values of samples are in the range of 0 and 1 , showing strong adsorption capacity as reported previously. ${ }^{65} 1 / \mathrm{n}$ values calculated from all adsorbents are in the range of 0 and 1.

Based on results calculated from Langmuir model, the maximum $\mathrm{As}(\mathrm{III})$ and $\mathrm{As}(\mathrm{V})$ removal amounts with $\mathrm{NH}_{4}{ }^{-}$ $\mathrm{NZ}-\mathrm{Y}$ are found as $28.7 \mathrm{mg} \mathrm{g}^{-1}$ and $36.6 \mathrm{mg} \mathrm{g}^{-1}$, respectively. The high adsorption capacity of $\mathrm{NH}_{4}-\mathrm{NZ}-\mathrm{Y}$ is a result of increasing adsorption sites with increasing surface area via decationisation as well as increasing surface acidity.

$\mathrm{D}-\mathrm{R}$ isotherm model gives information on physical or chemical adsorption of adsorption process. Activation energy variations (E) are $\mathrm{E}<8 \mathrm{~kJ} / \mathrm{mol}$ for physical adsorption and $8<\mathrm{E}<16.8 \mathrm{~kJ} / \mathrm{mol}$ for chemical adsorption in which energy is needed for removing a molecule from its location into the surface of adsorbent. ${ }^{66}$

From the linear fitting of D-R model, the obtained $\mathrm{R}^{2}$ values for $\mathrm{As}(\mathrm{V})$ are higher than those of $\mathrm{As}(\mathrm{III})$ and $\mathrm{E}$ values for all samples in Table 4 are lower than $8 \mathrm{~kJ} / \mathrm{mol}$, indicating that the mechanism of adsorption is physical process.

Influence of temperature on adsorption of arsenic was studied and is shown in Figs. 6 and 7. The adsorption

Table 4. Kinetic parameters for adsorption of As (III\&V) by NZ-Y, NH4-NZ-Y and Al-NZ-7 in water.

\begin{tabular}{|c|c|c|c|c|c|c|c|c|c|c|}
\hline \multirow[t]{2}{*}{ Adsorbent } & \multirow[b]{2}{*}{$\mathrm{q}_{\mathrm{e}}(\mathrm{mg} / \mathrm{g})$} & \multicolumn{3}{|c|}{ Pseudo first order } & \multicolumn{3}{|c|}{ Pseudo second order } & \multicolumn{3}{|c|}{ Intraparticle diffusion } \\
\hline & & $\mathrm{k}_{1}$ & $\mathrm{q}_{\mathrm{e}}(\mathrm{mg} / \mathrm{g})$ & $\mathbf{R}^{2}$ & k & $\mathrm{q}_{\mathrm{e}}(\mathrm{mg} / \mathrm{g})$ & $\mathbf{R}^{2}$ & $\mathbf{k}_{\mathrm{d}}$ & $\mathrm{C}(\mathrm{mg} / \mathrm{g})$ & $\mathbf{R}^{2}$ \\
\hline \multicolumn{11}{|c|}{ As(III) } \\
\hline NZ-Y & 2.69 & 0.002 & 1.37 & 0.24 & 0.017 & 2.57 & 0.94 & 0.067 & 1.24 & 0.23 \\
\hline $\mathrm{NH}_{4}-\mathrm{NZ}-\mathrm{Y}$ & 26.99 & 0.004 & 4.03 & 0.81 & 0.0003 & 38.02 & 0.98 & 1.175 & 5.45 & 0.89 \\
\hline \multicolumn{11}{|c|}{$\operatorname{As}(\mathrm{V})$} \\
\hline NZ-Y & 5.06 & 0.033 & 1.24 & 0.99 & 0.052 & 5.13 & 0.98 & 0.217 & 2.99 & 0.23 \\
\hline $\mathrm{NH}_{4}-\mathrm{NZ}-\mathrm{Y}$ & 30.23 & 0.043 & 4.81 & 0.74 & 0.001 & 32.25 & 0.99 & 0.749 & 14.89 & 0.44 \\
\hline Al-NZ-Y & 5.79 & 0.055 & 1.79 & 0.66 & 0.022 & 5.99 & 0.99 & 0.141 & 3.70 & 0.29 \\
\hline
\end{tabular}

Table 5. Adsorption constants for removal of arsenic (III, V) from aqueous solution with natural and modified zeolites

\begin{tabular}{|c|c|c|c|c|c|c|c|c|c|c|}
\hline \multirow[t]{2}{*}{ Adsorbent } & \multicolumn{3}{|c|}{ Freundlich isotherm } & \multicolumn{3}{|c|}{ Langmuir isotherm } & \multicolumn{4}{|c|}{ D-R isotherm } \\
\hline & $\begin{array}{c}\mathbf{k}_{\mathbf{F}} \\
\left(\mathbf{m g ~ g}^{-1}\right)\left(\mathbf{m g ~ L}^{-1}\right)^{-n}\end{array}$ & $1 / n$ & $\mathbf{R}^{2}$ & $\underset{(\mathrm{mg} / \mathrm{g})}{\mathrm{q}_{\mathrm{m}}}$ & b (L/mg) & $\mathbf{R}^{2}$ & $\underset{(\mathrm{mol} / \mathrm{g})}{\mathrm{q}_{\mathrm{s}}}$ & $\begin{array}{c}\mathbf{k} \\
\left(\mathbf{m o l}^{2} / \mathbf{J}^{2}\right)\end{array}$ & $\begin{array}{c}\mathrm{E} \\
(\mathrm{kJ} / \mathrm{mol})\end{array}$ & $\mathbf{R}^{2}$ \\
\hline \multicolumn{11}{|c|}{ As(III) } \\
\hline NZ-Y & 6.40 & 0.22 & 0.86 & 2.2 & 0.11 & 0.99 & 4.29 & 2.472 & 0.446 & 0.01 \\
\hline $\mathrm{NH}_{4}-\mathrm{NZ}-\mathrm{Y}$ & 474.71 & 0.10 & 0.99 & 28.7 & 0.46 & 0.98 & 28.85 & 2.976 & 0.409 & 0.21 \\
\hline \multicolumn{11}{|c|}{$\operatorname{As}(\mathrm{V})$} \\
\hline NZ-Y & 1.74 & 0.34 & 0.92 & 12.3 & 0.024 & 0.96 & 73.27 & 139.58 & 0.059 & 0.88 \\
\hline $\mathrm{NH}_{4}-\mathrm{NZ}-\mathrm{Y}$ & 64.97 & 0.12 & 0.97 & 36.6 & 0.22 & 0.99 & 9.81 & 141.63 & 0.059 & 0.90 \\
\hline Al-NZ-Y & 0.66 & 0.58 & 1.00 & 18.8 & 0.01 & 0.99 & 18.61 & 136.3 & 0.060 & 0.89 \\
\hline
\end{tabular}



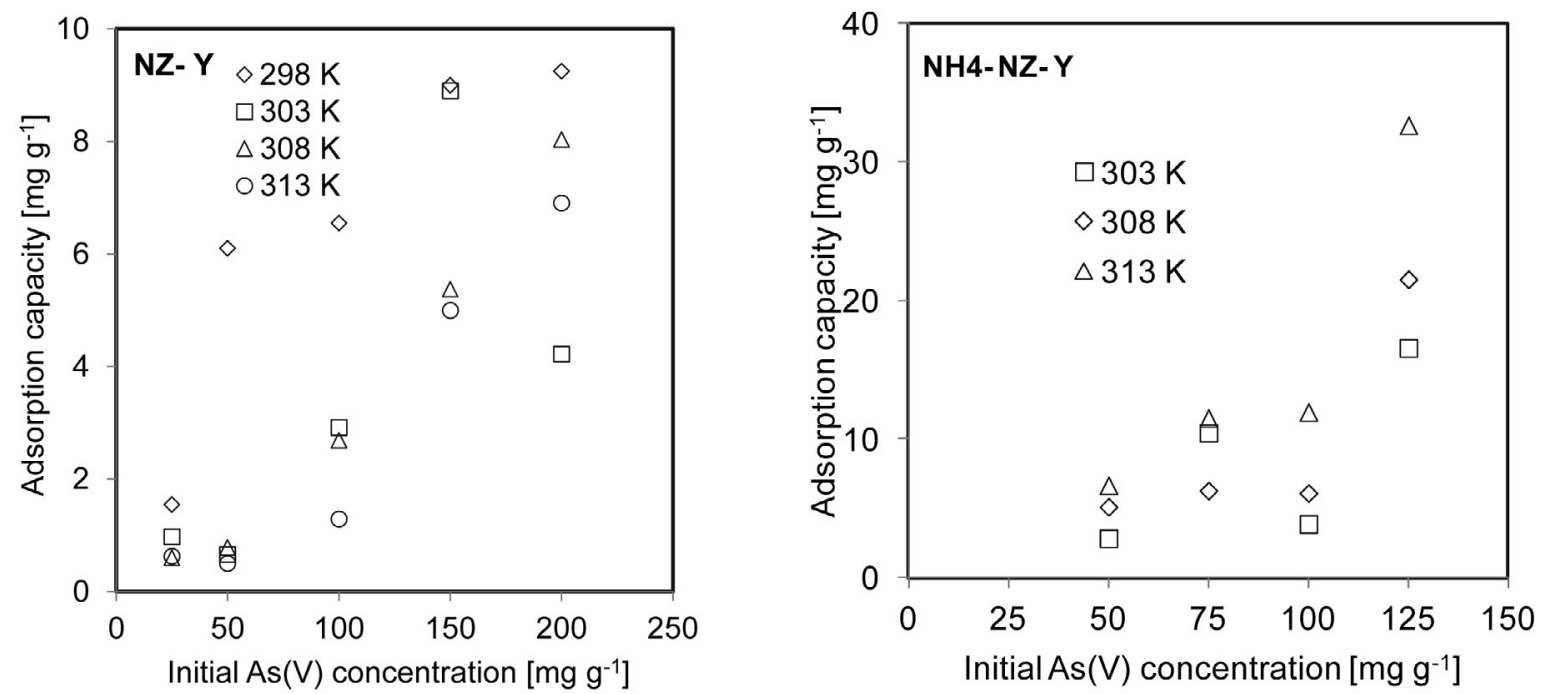

Figure 6. Adsorption capacity of NZ-Y and NH4-NZ-Y for removal of As(V) at different temperatures as a function of initial As(V) concentration.

Table 6. Thermodynamic data for As (III\&V) on $\mathrm{NH}_{4}-\mathrm{NZ}-\mathrm{Y}$

\begin{tabular}{|c|c|c|c|c|c|c|}
\hline Adsorbent & $\begin{array}{c}\text { As (III) } \\
\text { concentration }\end{array}$ & $\begin{array}{c}\mathbf{T} \\
(\mathrm{K})\end{array}$ & $\begin{array}{c}\Delta \mathrm{G} \\
(\mathrm{kJ} / \mathrm{mol})\end{array}$ & $\begin{array}{c}\Delta \mathrm{H} \\
(\mathrm{kJ} / \mathrm{mol})\end{array}$ & $\begin{array}{c}\Delta S \\
(\mathrm{~J} / \mathrm{mol} \mathrm{K})\end{array}$ & $\mathbf{R}^{2}$ \\
\hline \multirow[t]{16}{*}{$\mathrm{NH}_{4}-\mathrm{NZ}-\mathrm{Y}$} & $50 \mathrm{mg} / \mathrm{L}$ & 298 & -19.95 & -99.0 & -264.9 & 0.99 \\
\hline & & 303 & -18.90 & & & \\
\hline & & 308 & - & & & \\
\hline & & 313 & 16.02 & & & \\
\hline & $75 \mathrm{mg} / \mathrm{L}$ & 298 & -16.19 & -14.51 & 5.61 & 0.99 \\
\hline & & 303 & -16.21 & & & \\
\hline & & 308 & - & & & \\
\hline & & 313 & -16.28 & & & \\
\hline & $100 \mathrm{mg} / \mathrm{L}$ & 298 & -14.37 & 39.40 & 180.51 & 0.99 \\
\hline & & 303 & -15.32 & & & \\
\hline & & 308 & -16.17 & & & \\
\hline & & 313 & -16.75 & & & \\
\hline & $125 \mathrm{mg} / \mathrm{L}$ & 298 & - & 22.85 & 122.57 & 0.98 \\
\hline & & 303 & -14.31 & & & \\
\hline & & 308 & -14.84 & & & \\
\hline & & 313 & -15.54 & & & \\
\hline \multirow[t]{13}{*}{$\mathrm{NH}_{4}-\mathrm{NZ}-\mathrm{Y}$} & As $(\mathrm{V})$ concentration & & & & & \\
\hline & $50 \mathrm{mg} / \mathrm{L}$ & 303 & -9.1 & 71.4 & 266.2 & 0.96 \\
\hline & & 308 & -10.8 & & & \\
\hline & & 313 & -11.8 & & & \\
\hline & $75 \mathrm{mg} / \mathrm{L}$ & 303 & -13.1 & -14.9 & -6.17 & 0.98 \\
\hline & & 308 & -13.1 & & & \\
\hline & & 313 & -13.0 & & & \\
\hline & $100 \mathrm{mg} / \mathrm{L}$ & 303 & -9.1 & 95.0 & 343.4 & 0.98 \\
\hline & & 308 & -10.5 & & & \\
\hline & & 313 & -12.6 & & & \\
\hline & $125 \mathrm{mg} / \mathrm{L}$ & 303 & -12.4 & 64.9 & 255.1 & 0.97 \\
\hline & & 308 & -13.4 & & & \\
\hline & & 313 & -15.0 & & & \\
\hline
\end{tabular}

capacity of $\mathrm{NZ}-\mathrm{Y}$ and $\mathrm{NH}_{4}-\mathrm{NZ}-\mathrm{Y}$ for As (V) and of $\mathrm{NH}_{4}^{-}$ $\mathrm{NZ}-\mathrm{Y}$ for As(III) increases with increasing temperature, indicating endothermic nature of arsenic adsorption.
However, the removal amount of As (III) on NZ-Y decreased with increasing temperature due to its exothermic nature. 

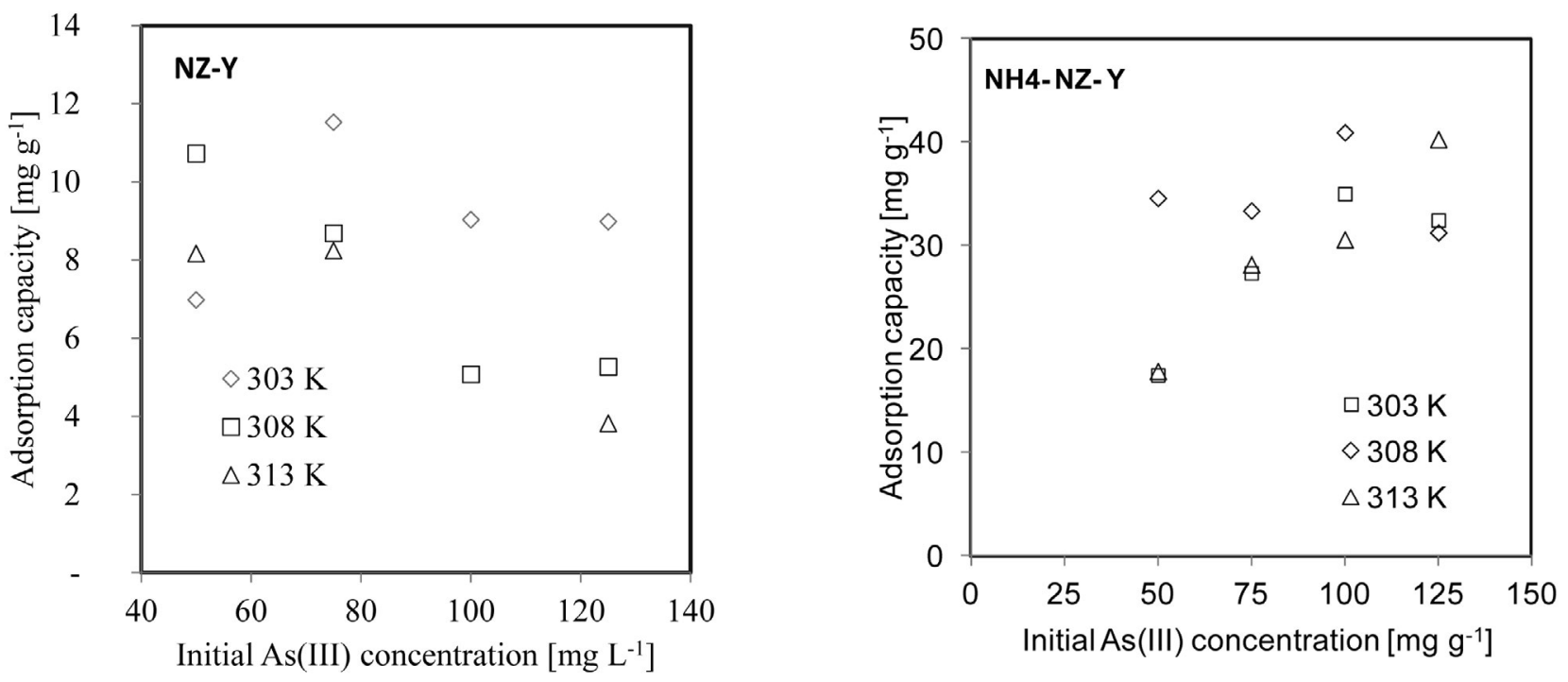

Figure 7. Adsorption capacity of NZ-Y and NH4-NZ-Y for removal of As(III) at different temperatures as a function of initial As(III) concentration

Thermodynamic parameters for adsorption of As (III\&V) on $\mathrm{NH}_{4}$-NZ-Y with high arsenic adsorption capacity were calculated using experimental results in Fig. 6 and 7 via equations (13 and 14 ) in section 2.3 and the results are listed in Table 6. The Gibbs free energies were found as negative for $\mathrm{NH}_{4}-\mathrm{NZ}-\mathrm{Y}$, indicating that the adsorption of arsenic on $\mathrm{NH}_{4}-\mathrm{NZ}-\mathrm{Y}$ is feasible and spontaneous (Table 6). The positive values of $\Delta \mathrm{H}^{\circ}$ for $\mathrm{NH}_{4}-\mathrm{NZ}-\mathrm{Y}$ supported the endothermic nature of adsorption process. The positive values of $\Delta \mathrm{S}^{\circ}$ for $\mathrm{NH}_{4}-\mathrm{NZ}$-Y increase with increasing initial concentration of $\mathrm{As}(\mathrm{III} \& \mathrm{~V})$,supporting randomness on the solid-liquid interface.

\section{2. 4. Comparison of Results With Literature}

The comparison of results with literature shows that the adsorption capacity of NZ-Y varies with source, composition and modification of NZ as seen in Table 7. The results of NZ-Y for $\mathrm{As}(\mathrm{V})$ are consistent with Slovakia clinoptilolite reported by Dousova et al.. ${ }^{67}$ Adsorption results of the modified zeolites with $\mathrm{NH}_{4}{ }^{+}$is similar to synthetic zeolites reported by Chutia et al. ${ }^{59}$ However, the effect of Al modification on arsenic adsorption capacity of zeolite varies with source and composition of zeolite. Although the influence of $\mathrm{Al}$ on Gordes-clinoptilolite ${ }^{68}$ for $\mathrm{As}(\mathrm{V})$ adsorption is low, its effect on montmorillonite ${ }^{69}$ is significant. In this study, the findings on Sivas- Yavu zeolitic tuff for $\mathrm{As}(\mathrm{V})$ are in accordance with montmorillonite, which may be associated with significant mordenite content and high surface area of NZ-Y.

\section{Conclusion}

Natural zeolite obtained from Sivas-Yavu region of Turkey was modified with ion-exchange using $\mathrm{NH}_{4} \mathrm{NO}_{3}$ and introduction of aluminum using $\mathrm{Al}_{2}\left(\mathrm{SO}_{4}\right)_{3}$. Chemical and physical properties of natural and modified zeolites were characterized by various techniques such as XRF, XRD, $\mathrm{N}_{2}$ sorption, FTIR, $\mathrm{NH}_{3}-\mathrm{TPD}$, zeta potential and SEM. The influence of specific adsorption parameters on removal of arsenic from aqueous solution was studied and the data obtained were applied to isotherm models. From the experimental results it can be concluded that adsorption of arsenic depends on the textural properties such as composition, the size and distribution of pores and crystal structure of the adsorbate. Ion exchange and aluminum introduction increased the arsenic adsorption capacity of natural zeolite. The Langmuir isotherm model was best fitted to the isotherm data obtained. In addition, D-R isotherms showed physical adsorption of arsenic on the natural and modified zeolites. Based on thermodynamic investigation, whereas adsorption of As(III) with natural zeolite has exothermic nature, the adsorption of As (III $\& \mathrm{~V}$ ) with $\mathrm{NH}_{4}{ }^{+}$exchanged zeolite is endothermic.

\section{Acknowledgements}

I gratefully acknowledge the financial support of this work by Research fond of Cumhuriyet University (M-492) and The Scientific \& Technology Research Council of Turkey (TUBİTAK) (113M813).

\section{References}

1. WHO, Guidelines for drinking-water quality (4 ed)World Health Organization, Geneva, Switzerland, 1993.

2. T. Tuutijärvi, J. Lu, M. Sillanpää, G. Chen, J. Hazard. Mater. 2009, 166, 1415-1420. DOI:10.1016/j.jhazmat.2008.12.069 
Table 7. Comparison of adsorption capacities of different types of zeolites

\begin{tabular}{|c|c|c|c|c|c|}
\hline Adsorbent & Treatment & Metal oxide & As(III) ( mg/g) & As (V) (mg/g) & Reference \\
\hline \multirow{2}{*}{ Zeolitic tuff(ZMA) } & - & - & - & 0.004 & \multirow{2}{*}{$\begin{array}{l}\text { Elizalde-González } \\
\text { et al. }{ }^{70}\end{array}$} \\
\hline & - & - & - & 0.0018 & \\
\hline Zeolite & HDTMA & & & 0.539 & Li et al ${ }^{71}$ \\
\hline Clinoptilolite & $\mathrm{NaCl}$ & & & 0.428 & Chutia et al..$^{59}$ \\
\hline Winston clinoptilolite & - & $\mathrm{FeCl}_{3}, \mathrm{FeSO}_{4}$ & - & 0.05 & Li et al. ${ }^{72}$ \\
\hline \multirow{2}{*}{ Tehuacan natural zeolite } & \multirow{2}{*}{$\mathrm{NaCl}$} & $\mathrm{FeCl}_{3}$ & 0.06 & 0.186 & \multirow{2}{*}{ Jiménez-Cedillo ${ }^{40}$} \\
\hline & & $\mathrm{MnCl}_{2}$ & 0.06 & 0.170 & \\
\hline Mexica clinoptilolite & $\mathrm{NaCl}$ & $\mathrm{FeCl}_{3}$ & 0.01 & $0.022-0.053$ & MacEdo-Miranda et al. ${ }^{42}$ \\
\hline Clinoptilolite & - & $\mathrm{FeCl}_{3}$ & - & 0.68 & Jeon et al. ${ }^{73}$ \\
\hline Mexica clinoptilolite & $\mathrm{NaCl}$ & $\mathrm{FeCl}_{3}$ & 0.012 & 0.006 & Davilla-Jimenez et al. ${ }^{74}$ \\
\hline Gordes clinoptilolite & $\mathrm{NaCl}$ & $\mathrm{FeCl}_{3}$ & - & $0.0084-0.0092$ & Baskan and Pala ${ }^{75}$ \\
\hline Slovakia clinoptilolite & - & $\mathrm{FeSO}_{4}$ & - & 18.0 & Dousová et al. ${ }^{76}$ \\
\hline Montmorillonite & - & $\mathrm{AlCl}_{3}$ and $\mathrm{FeCl}_{3}$ & 19.11 & 21.23 & Ramesh et al. ${ }^{77}$ \\
\hline \multirow{3}{*}{ Gordes clinoptilolite } & \multirow{3}{*}{$\mathrm{NaCl}$} & $\mathrm{FeCl}_{2}$ & - & 3.02 & \multirow{3}{*}{ Simsek et al. ${ }^{78}$} \\
\hline & & $\mathrm{FeCl}_{2}$ and $\mathrm{AlCl}_{3}$ & - & 3.86 & \\
\hline & & $\mathrm{AlCl}_{3}$ & - & 1.60 & \\
\hline Synthetic zeolite & - & - & - & 35.89 & Chutia et al. ${ }^{39}$ \\
\hline \multirow{3}{*}{ Sivas- Yavu-clinoptilolite } & - & - & 1.1 & 12.33 & \multirow{3}{*}{ This study } \\
\hline & & $\mathrm{NH}_{4} \mathrm{NO}_{3}$ & 28.7 & 36.6 & \\
\hline & & $\mathrm{Al}_{2}\left(\mathrm{SO}_{4}\right)_{3}$ & - & 18.83 & \\
\hline
\end{tabular}

3. W. Song, M. Zhang, J. Liang, G. Han, J. Mol. Liq. 2015, 206, 262-267. DOI:10.1016/j.molliq.2015.03.007

4. A. Nilchi, S. R. Garmarodi, S. J. Darzi, J. Appl. Polym. Sci. 2011, 119, 3495-3503. DOI:10.1002/app.33003

5. Z. Li, J.-S. Jean, W.-T. Jiang, P.-H. Chang, C.-J. Chen, L. Liao, J. Hazard. Mater. 2011, 187, 318-23.

DOI:10.1016/j.jhazmat.2011.01.030

6. P. Navarro, F. J. Alguacil, Hydrometallurgy. 2002, 66, 101-105. DOI:10.1016/S0304-386X(02)00108-1

7. C. L. Chuang, M. Fan, M. Xu, R. C. Brown, S. Sung, B. Saha, C. P. Huang, Chemosphere. 2005, 61, 478-483.

DOI:10.1016/j.chemosphere.2005.03.012

8. B. Daus, R. Wennrich, H. Weiss, Water Res. 2004, 38, 29482954. DOI:10.1016/j.watres.2004.04.003

9. Z. M. Gu, J. Fang, B. L. Deng, Environ. Sci. Technol. 2005, 39, 3833-3843. DOI:10.1021/es048179r

10. D. Mohan, S. Chander, J. Hazard. Mater. 2006, 137, 15451553. DOI:10.1016/j.jhazmat.2006.04.053

11. M. Fan, W. Marshall, D. Daugaard, R. C. Brown, Bioresour. Technol. 2004, 93, 103-107.

DOI:10.1016/j.biortech.2003.08.016

12. H. S. Altundoan, S. Altundoan, F. Tümen, M. Bildik, Waste Manag. 2002, 22, 357-363.

DOI:10.1016/S0956-053X(01)00041-1
13. F. S. Zhang, H. Itoh, Chemosphere. 2005, 60, 319-325. DOI:10.1016/j.chemosphere.2004.12.019

14. J. S. Ahn, C. M. Chon, H. S. Moon, K. W. Kim, Water Res. 2003, 37, 2478-2488.

DOI:10.1016/S0043-1354(02)00637-1

15. K. S. Low, C. K. Lee, Environ. Technol. 1995, 16, 65-71. DOI:10.1080/09593331608616246

16. A. Mittal, L. Kurup, V. K. Gupta, J. Hazard. Mater. 2005, 117, 171-178. DOI:10.1016/j.jhazmat.2004.09.016

17. H. Zhang, H. M. Selim, Environ. Sci. Technol. 2005, 39, 61016108. DOI:10.1021/es050334u

18. B. Petrusevski, S. K. Sharma, F. Kruis, P. Omeruglu, J. C. Schippers, in Water Science and Technology: Water Supply. 2002, 2, 127-133. DOI:10.2166/ws.2002.0160

19. C. Y. Jing, S. Q. Liu, M. Patel, X. G. Meng, Environ. Sci. Technol. 2005, 39, 5481-5487. DOI:10.1021/es050290p

20. M. Vithanage, W. Senevirathna, R. Chandrajith, R. Weerasooriya, Sci. Total Environ. 2007, 379, 244-248.

DOI:10.1016/j.scitotenv.2006.03.045

21. Y. Arai, D. L. Sparks, J. A. Davis, Environ. Sci. Technol. 2005, 39, 2537-2544. DOI:10.1021/es0486770

22. P. Lakshmipathiraj, B. R. Narasimhan, S. Prabhakar, G. B. Raju, J. Hazard. Mater. 2006, 136, 281-287.

DOI:10.1016/j.jhazmat.2005.12.015 
23. G. P. Gillman, Sci. Total Environ. 2006, 366, 926-931. DOI:10.1016/j.scitotenv.2006.01.036

24. K. B. Payne, T. M. Abel-Fattah, J. Environ. Sci. Heal. Part a-Toxic/Hazardous Subst. Environ. Eng. 2005, 40, 723-749.

25. M. Badruzzaman, P. Westerhoff, D. R. U. Knappe, Water Res. 2004, 38, 4002-4012. DOI:10.1016/j.watres.2004.07.007

26. S. Bang, M. Patel, L. Lippincott, X. Meng, Chemosphere. 2005, 60, 389-397. DOI:10.1016/j.chemosphere.2004.12.008

27. T. F. Lin, J. K. Wu, Water Res. 2001, 35, 2049-2057. DOI:10.1016/S0043-1354(00)00467-X

28. T. Nakajima, Y. H. Xu, Y. Mori, M. Kishita, H. Takanashi, S. Maeda, A. Ohki, J. Hazard. Mater. 2005, 120, 75-80. DOI:10.1016/j.jhazmat.2004.11.030

29. M. Pena, X. G. Meng, G. P. Korfiatis, C. Y. Jing, Environ. Sci. Technol. 2006, 40, 1257-1262. DOI:10.1021/es052040e

30. A. C. Q. Ladeira, V. S. T. Ciminelli, Water Res. 2004, 38, 2087-2094. DOI:10.1016/j.watres.2004.02.002

31. C. M. Su, R. W. Puls, Environ. Sci. Technol. 2003, 37, 25822587. DOI:10.1021/es026351q

32. Y. Kiso, Y. J. Jung, T. Yamada, M. Nagai, K. S. Min, Leading-Edge Technol. 2005 - Water Treat. 2005, 5, 75-81.

33. W. Lenoble, C. Laclautre, W. Deluchat, B. Serpaud, J. C. Bollinger, J. Hazard. Mater. 2005, 123, 262-268.

DOI:10.1016/j.jhazmat.2005.04.005

34. D. F. Martin, L. O’Donnell, B. B. Martin, R. Alldredge, J. Environ. Sci. Heal. Part a-Toxic/Hazardous Subst. Environ. Eng. 2007, 42, 97-102.

35. C. C. Chen, Y. C. Chung, J. Environ. Sci. Heal. Part a-Toxic/ Hazardous Subst. Environ. Eng. 2006, 41, 645-658.

36. D. Pokhrel, T. Viraraghavan, Water Res. 2006, 40, 549-552. DOI:10.1016/j.watres.2005.11.040

37. M. N. Haque, G. M. Morrison, G. Perrusquia, M. Gutierrez, A. R. Aguilera, I. Cano-Aguilera, J. L. Gardea-Torresdey, J. Hazard. Mater. 2007, 145, 30-35.

DOI:10.1016/j.jhazmat.2006.10.080

38. M. Srivastava, L. Q. Ma, J. A. G. Santos, Sci. Total Environ. 2006, 364, 24-31. DOI:10.1016/j.scitotenv.2005.11.002

39. P. Chutia, S. Kato, T. Kojima, S. Satokawa, J. Hazard. Mater. 2009, 162, 440-447. DOI:10.1016/j.jhazmat.2008.05.061

40. M. J. Jiménez-Cedillo, M. T. Olguín, C. Fall, A. Colín, Appl. Clay Sci. 2011, 54, 206-216. DOI:10.1016/j.clay.2011.09.004

41. M. P. Elizalde-González, J. Mattusch, W.-D. Einicke, R. Wennrich, Chem. Eng. J. 2001, 81, 187-195.

DOI:10.1016/S1385-8947(00)00201-1

42. M. G. MacEdo-Miranda, M. T. Olgun, J. Incl. Phenom. Macrocycl. Chem. 2007, 59, 131-142.

DOI:10.1007/s10847-007-9306-3

43. K. Margeta, Š. C. Stefanović, V. Kaučič, N. Z. Logar, Appl. Clay Sci. 2015, 116-117, 111-119.

DOI:10.1016/j.clay.2015.08.021

44. X. Jiang Hu, J. Song Wang, Y. Guo Liu, X. Li, G. Ming Zeng, Z. Lei Bao, X. Xia Zeng, A. Wei Chen, F. Long, J. Hazard. Mater. 2011, 185, 306-314.

45. M. Kamali, S. Vaezifar, H. Kolahduzan, A. Malekpour, M. R. Abdi, Powder Technol. 2009, 189, 52-56.

DOI:10.1016/j.powtec.2008.05.015
46. A. Ates, Powder Technol. 2014, 264, 86-95. DOI:10.1016/j.powtec.2014.05.023

47. Y. S. Ho, G. McKay, Water Res. 2000, 34, 735-742. DOI:10.1016/S0043-1354(99)00232-8

48. Y. C. Wong, Y. S. Szeto, W. H. Cheung, G. McKay, Process Biochem. 2004, 39, 693-702.

DOI:10.1016/S0032-9592(03)00152-3

49. H. Javadian, M. Ahmadi, M. Ghiasvand, S. Kahrizi, R. Katal, J. Taiwan Inst. Chem. Eng. 2013, 44, 977-989.

50. A. Günay, E. Arslankaya, I. Tosun, J. Hazard. Mater. 2007, 146, 362-371. DOI:10.1016/j.jhazmat.2006.12.034

51. H. Javadian, M. Taghavi, Appl. Surf. Sci. 2014, 289, 487-494. DOI:10.1016/j.apsusc.2013.11.020

52. A. Ates, C. Hardacre, J. Colloid Interface Sci. 2012, 372, 130 140. DOI:10.1016/j.jcis.2012.01.017

53. A. Ates, Powder Technol. 2014, 264, 86-95. DOI:10.1016/j.powtec.2014.05.023

54. S. J. Kang, K. Egashira, A. Yoshida, Appl. Clay Sci. 1998, 13, 117-135. DOI:10.1016/S0169-1317(98)00019-2

55. S. R. Taffarel, J. Rubio, Miner. Eng., 2010, 23, 1131-1138. DOI:10.1016/j.mineng.2010.07.007

56. M. Kamali, S. Vaezifar, H. Kolahduzan, A. Malekpour, M. R. Abdi, Powder Technol. 2009, 189, 52-56.

DOI:10.1016/j.powtec.2008.05.015

57. K. Zhang, V. Dwivedi, C. Chi, J. Wu, J. Hazard. Mater. 2010, 182, 162-168. DOI:10.1016/j.jhazmat.2010.06.010

58. A. Teutli-Sequeira, M. Solache-Ríos, V. Martínez-Miranda, I. Linares-Hernández, J. Colloid Interface Sci. 2014, 418, 254 260. DOI:10.1016/j.jcis.2013.12.020

59. P. Chutia, S. Kato, T. Kojima, S. Satokawa, J. Hazard. Mater. 2009, 162, 204-211. DOI:10.1016/j.jhazmat.2008.05.024

60. E. A. Deliyanni, D. N. Bakoyannakis, A. I. Zouboulis, K. A. Matis, Chemosphere. 2003, 50, 155-163.

DOI:10.1016/S0045-6535(02)00351-X

61. D. Fu, Z. He, S. Su, B. Xu, Y. Liu ,Y. Zhao, J. Colloid Interface Sci. 2017, 505, 105-114. DOI:10.1016/j.jcis.2017.05.091

62. G. A. Waychunas, J. A. Davis, C. C. Fuller, Geochim. Cosmochim. Acta. 1995, 59, 3655-3661.

DOI:10.1016/0016-7037(95)00276-6

63. G. Zhang, J. Qu, H. Liu, R. Liu, R. Wu, Water Res. 2007, 41, 1921-1928. DOI:10.1016/j.watres.2007.02.009

64. P. K. Dutta, A. K. Ray, V. K. Sharma, F. J. Millero, J. Colloid Interface Sci. 2004, 278, 270-275.

DOI:10.1016/j.jcis.2004.06.015

65. N. D. Hutson, R. T. Yang, Adsorption. 1997, 3, 189-195. DOI:10.1007/BF01650130

66. K. Y. Foo, B. H. Hameed, Chem. Eng. J. 2010, 156, 2-10. DOI:10.1016/j.cej.2009.09.013

67. B. Dousová, T. Grygar, A. Martaus, L. Fuitová, D. Kolousek, V. Machovic, J. Colloid Interface Sci. 2006, 302, 424-431. DOI:10.1016/j.jcis.2006.06.054

68. E. B. Simsek, E. Özdemir, U. Beker, Chem. Eng. J. 2013, 220, 402-411. DOI:10.1016/j.cej.2013.01.070

69. A. Ramesh, H. Hasegawa, T. Maki, K. Ueda, Sep. Purif. Technol. 2007, 56, 90-100.

70. M. P. Elizalde-Gonz??lez, J. Mattusch, W. D. Einicke, R. Wen- 
nrich, Chem. Eng. J. 2001, 81, 187-195.

71. Z. Li, R. Beachner, Z. McManama, H. Hanlie, Microporous Mesoporous Mater. 2007, 105, 291-297.

DOI:10.1016/j.micromeso.2007.03.038

72. Z. Li, J.-S. Jean, W.-T. Jiang, P.-H. Chang, C.-J. Chen, L. Liao, J. Hazard. Mater. 2011, 187, 318-323.

DOI:10.1016/j.jhazmat.2011.01.030

73. C.-S. Jeon, K. Baek, J.-K. Park, Y.-K. Oh, S.-D. Lee, J. Hazard. Mater. 2009, 163, 804-808.

DOI:10.1016/j.jhazmat.2008.07.052

74. M. M. Dávila-Jiménez, M. P. Elizalde-González, J. Mattusch, P. Morgenstern, M. A. Pérez-Cruz, Y. Reyes-Ortega, R. Wen- nrich, H. Yee-Madeira, J. Colloid Interface Sci. 2008, 322, 527-536. DOI:10.1016/j.jcis.2008.03.042

75. M. Bilici Baskan, A. Pala, Desalination. 2011, 281, 396-403.

DOI:10.1016/j.desal.2011.08.015

76. B. Doušová, T. Grygar, A. Martaus, L. Fuitová, D. Koloušek, V. Machovič, J. Colloid Interface Sci. 2006, 302, 424-431. DOI:10.1016/j.jcis.2006.06.054

77. A. Ramesh, H. Hasegawa, T. Maki, K. Ueda, Sep. Purif. Technol. 2007, 56, 90-100. DOI:10.1016/j.seppur.2007.01.025

78. E. B. Simsek, E. Özdemir, U. Beker, Chem. Eng. J. 2013, 220, 402-411. DOI:10.1016/j.cej.2013.01.070

\section{Povzetek}

Preučevali smo adsorpcijo arzena iz vodnih raztopin na naravni zeolit (NZ), zeolit predhodno izpostavljen raztopini $\mathrm{NH}_{4} \mathrm{NO}_{3}$ in zeolit izpostavljen raztopni $\mathrm{Al}_{2}\left(\mathrm{SO}_{4}\right)_{3}$. Zeoliti so bili okarakterizirani z XRF, XRD, $\mathrm{N}_{2}$ adsorpcijo, FTIR, $\mathrm{NH}_{3}$-TPD, zeta potencialom in SEM. Zeolit predhodno obdelan $\mathrm{z} \mathrm{NH}_{4}{ }^{+}$kaže znatno ionsko izmenjavo $\mathrm{z}$ večino kationov ter povečanje specifične površine, poroznosti in površinske kislosti. Prisotnost aluminija $\mathrm{v}$ zeolitu je povečala adsorpcijo $\mathrm{As}(\mathrm{V})$ in znižala adsorpcijo As (III) medtem ko izpostavljenost naravnega zeolita $\mathrm{NH}_{4}{ }^{+}$ionom povzroči povečanje adsorpcijske kapacitete obeh zvrsti. Hitrost adsorpcije obeh zvrsti arzena na naravni in modificirana zeolita lahko opišemo s kinetiko pseudo-drugega reda, adsorpcijsko ravnotežje pa z Langmuirjevo izotermo. Najvišjo adsorpcijsko kapaciteto kaže zeolit izpostavljen vodni raztopini amonijaka in znaša $28.7 \mathrm{mg} / \mathrm{g}$ za As(III) in $36.6 \mathrm{mg} / \mathrm{g}$ za As(V). Izračunani termodinamski parametri kažejo, da je adsorpcijski proces spontan in ravnotežje ugodno. 